\title{
Growth and production of Sterechinus neumayeri (Echinoidea: Echinodermata) in McMurdo Sound, Antarctica
}

Received: 16 June 1995/Accepted: 19 August 1995

\begin{abstract}
Population dynamics of Sterechinus neumayeri were investigated at four sites in McMurdo Sound: Cape Evans, McMurdo Station, East Cape Armitage and New Harbor. The annual formation of natural growth bands in the jaws of the Aristotle's lantern was verified by a tagging-recapture experiment. Growth functions based on natural growth bands indicated differences among stations but showed $S$. neumayeri to be a slow growing species, reaching its maximum diameter of $70 \mathrm{~mm}$ at an age of about $40 \mathrm{yr}$. Annual production ranged between 2.4 (C. Evans) and $0.65 \mathrm{~g}$ ash free dry mass $\mathrm{m}^{-2}$ (New Harbor) and was related to differences in food conditions. More than $95 \%$ of total production was invested in reproduction, and less than $5 \%$ was invested in somatic growth. Consumption estimates for $S$. neumayeri showed this species to play a significant role in the benthic trophic web of McMurdo Sound.
\end{abstract}

\section{Introduction}

Sterechinus neumayeri is the most abundant regular sea urchin in shallow Antarctic waters, being circumant-

Communicated by $\mathrm{O}$. Kinne, Oldendorf/Luhe

T. Brey (可)

Institute for Polar and Marine Research, Columbusstrasse,

D-27568 Bremerhaven, Germany

J. Pearse

Institute of Marine Sciences, University of California,

Santa Cruz, California 95064, USA

L. Basch

Scripps Institution of Oceanography, Marine Life Research Group, La Jolla, California 92093-0201, USA

J. McClintock

Department of Biology, The University of Alabama at Birmingham, Alabama 35294, USA

M. Slattery

University of Guam, Marine Laboratory, UOG Station,

Mangilao, Guam 96923, USA arctic and subantarctic (to Kerguelen Island), and extending from the shore down to about $400 \mathrm{~m}$ water depth (Pawson 1969; Brey and Gutt 1991). Below this depth, the closely related species $S$. antarcticus is more abundant, which was found to show extremely slow growth $(60 \mathrm{~mm}$ diameter at about $70 \mathrm{yr}$ of age, see Brey 1991).

Sterechinus neumayeri is common on the western shores of Ross Island in McMurdo Sound, where it feeds mainly on benthic diatoms (reviewed by McClintock 1994) as well as on red algae and seal faeces (Dearborn 1965; Pearse and Giese 1966; Basch and Slattery unpublished). In deeper waters below the euphotic zone organic surface deposits are the primary food (observations from the Weddell Sea shelf, Brey unpublished). Predators of $S$. neumayeri include the starfish Odontaster validus, Macroptychaster accrescens and Porania antarctica glabra (McClintock 1994), and the sea anemone Urticinopsis antarcticus (Dayton et al. 1970 ). It is likely that $S$. neumayeri is also preyed upon by other invertebrate as well as vertebrate predators. Spawning occurs in late austral spring to early summer (Pearse and Giese 1966; Yakovlev 1983), after an extended period of gametogenesis, with oogenesis requiring nearly 2 yr (Pearse and Bosch 1991). Development takes place in the water column and includes a typical pluteus larva; settlement and metamorphosis occur nearly 4 mo after fertilization (Bosch et al. 1987).

It is well established that individual sea urchin growth is strongly affected by habitat variability, especially food conditions (e.g. Ebert 1968). Hence, the purpose of this paper is to analyze the effects of contrasting environmental conditions at four sites in McMurdo Sound, Antarctica, on individual growth and population production of Sterechinus neumayeri. Moreover, we evaluate the significance of this sea urchin in the trophic web and energy flow of this high-Antarctic shallow water ecosystem. 


\section{Methods}

Sampling sites and sampling

Populations of $S$. neumayeri were investigated at four different sites within McMurdo Sound: Cape Evans, McMurdo Station and East Cape Armitage located on the eastern side of the Sound, and New Harbor located on the western side (Fig. 1). The four sites have been described extensively by Dayton et al. (1974), Dayton and Oliver (1977), Dayton et al. (1986), McClintock et al. (1988), Knox (1990), Miller and Pearse (1991) and references therein. Table 1 summarizes the main physical and biological characteristics of these sites. Although strong year-to-year variations have to be considered, there are marked differences among the four sites: C. Evans and McMurdo Station are situated on the eastern side of the Sound, which is characterized by a tidally affected current regime, with a net water movement of about $6.8 \mathrm{~km} \mathrm{~d}^{-1}$ from north to south. New Harbor, on the western side of the Sound, as well as E. C. Armitage are exposed to currents moving northward from under the ice shelf. On the eastern side of the Sound there is an ice free period of about 3 to $5 \mathrm{mo} \mathrm{yr}^{-1}$. The sea is ice free along the western side and at E. C. Armitage for only a short period in late summer, or not at all.

Correlated with the southerly current regime is a high level of pelagic primary production, as most of the pelagic production in McMurdo Sound results from advection of phytoplankton blooms from the open Ross Sea (Dayton and Oliver 1977; Knox 1990; Rivkin 1991). Pelagic primary production on the western side (New Harbor) is lower, and may be even lower at E. C. Armitage which does not benefit from this advection process at all. Sea-ice primary production depends mainly on the thickness of the snow layer on top of the ice, and may exhibit a small scale spatial distribution not related to the current regime in the Sound. Benthic microalgal production has not been measured directly, but, from differences in standing stock during the austral summer, Knox (1990) estimated minimum production on the eastern side to be about nine times higher than on the western side of the Sound. At C. Evans, dense standing stocks of red algae (Iridaea cordata and Phyllophora antarctica, Miller and Pearse 1991) occur, but their contribution to primary production is not known. Macrozoobenthic abundance is much higher on the eastern side than on the western side of the Sound, and presumably lowest at E. C. Armitage.

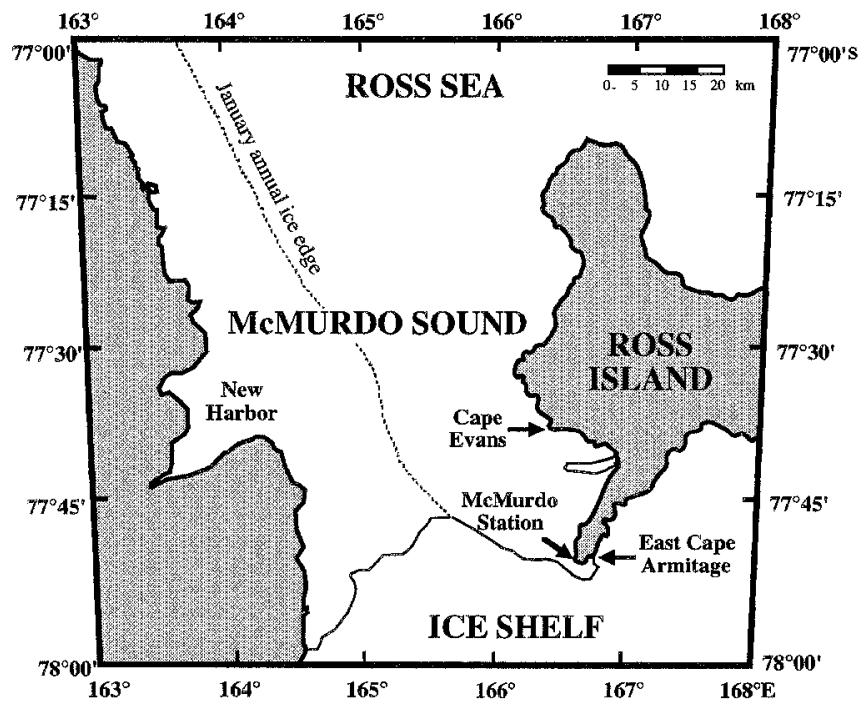

Fig. 1 Map of McMurdo Sound, Antarctica, showing the location of the four sampling sites
Abundance estimates

All counting, sampling and experimental work at the four sites was carried out using SCUBA. In Jan/Feb 1991 the abundance of Sterechinus neumayeri was estimated at C. Evans, McMurdo Station and New Harbor. At each station, three transects were run parallel to the shore between 20 and $25 \mathrm{~m}$ water depth, and ten quadrates $\left(1 \mathrm{~m}^{-2}\right)$ placed randomly along the transects were counted. In Sep 1993 divers estimated average abundance of $S$. neumayeri at $C$. Evans counting sea urchins along seven transects of $1 \mathrm{~m}$ width and $25 \mathrm{~m}$ length situated between 3 and $21 \mathrm{~m}$ water depth.

\section{Tagging and recapture at McMurdo Station}

More than 260 Sterechinus neumayeri were collected on 5 Dec 1989 in 15 to $18 \mathrm{~m}$ depth. About 110 specimens were transferred to the laboratory, the remaining 150 were held in mesh bags in sea water until the following day. These specimens were then injected with 1 to $3 \mathrm{ml}$ (depending on sea urchin size) solution of tetracycline in filtered sea water $\left(10 \mathrm{mg} \mathrm{ml}^{-1}\right)$. Tetracycline binds to sites of calcification, producing a fluorescent mark visible in ultra-violet light (Kobayashi and Taki 1969; Pearse and Pearse 1975). A total of 15 ind were placed in each of two cages $(122 \times 122 \times 15 \mathrm{~cm})$ made of plastic coated mesh $(2.5 \mathrm{~cm})$ hardware cloth in about $15 \mathrm{~m}$ water depth in front of McMurdo Station. The remaining 120 ind were placed in three additional cages nearby and released a few days later. The time lag between tagging and release was conducted to allow sea urchins to recover from possible negative effects of handling and treatment with tetracycline. (During a previous experiment in 1984 all specimens were released directly after tetracycline injection and were killed within a few days by the starfish Odontaster validus.) On 6 Dec 1990 , the two cages were removed from the sea bottom, and the surviving 26 ind were dried for later analysis. On the same day 104 free ranging specimens were collected from the release site and also dried. Of these, 34 turned out to be tagged (i.e., recovery rate $=28 \%$ ).

\section{Sampling at Cape Evans}

On 4 Dec 1992, 487 ind of Sterechinus neumayeri were haphazardly collected from 6 to $8 \mathrm{~m}$ depth. Based on 40 specimens of various body size, relations between dry body mass, dry gonad mass and size were established. The lanterns of 150 ind were removed and preserved in ethanol for later growth analysis.

Sampling at East Cape Armitage and New Harbor

Abundance of Sterechinus neumayeri is very low at these two sites. A total of 16 and 7 specimens were collected and dried in 1991 from New Harbor and E. C. Armitage, respectively.

Growth analysis

Growth was estimated from annual growth increments identifiable in the tetracycline-tagged individuals (McMurdo Station) as well as from natural growth bands (McMurdo Station, Cape Evans, New Harbor, E.C. Armitage). For growth analysis we used the jaws (i.e. half pyramids) of Aristotle's lantern, in which growth bands are more conspicuous than in other skeletal elements (Brey 1991). After measuring the horizontal diameter of the test, the lantern was removed, cleaned of attached organic matter and separated into its elements by treatment in hot $5 \% \mathrm{NaOCl}$ solution. The jaws were subsequently washed in $95 \%$ ethanol and dried. Jaw size was 
Table 1 Characteristics of the four sites investigated at Cape Evans, McMurdo Station, East Cape Armitage and New Harbor. Data based on Barry (1988), Barry and Dayton (1988), Barry et al. (1994), Dayton and Oliver (1977), Dayton et al. (1974), Dayton et al. (1986), Knox (1990), McClintock et al. (1988), Miller and Pearse (1991), Rivkin (1991) and references therein

\begin{tabular}{|c|c|c|c|c|}
\hline Characteristics & Cape Evans & $\begin{array}{l}\text { McMurdo } \\
\text { Station }\end{array}$ & $\begin{array}{l}\text { East Cape } \\
\text { Armitage }\end{array}$ & New Harbor \\
\hline Currents & $\begin{array}{l}\text { tidal, } \\
\text { southerly trend }\end{array}$ & $\begin{array}{l}\text { tidal, } \\
\text { southerly trend }\end{array}$ & $\begin{array}{l}\text { mostly } \\
\text { westwards }\end{array}$ & $\begin{array}{l}\text { constant \& slow } \\
\text { northwards }\end{array}$ \\
\hline $\begin{array}{l}\text { Sea ice } \\
\text { Max. thickness } \\
\text { Snow cover }\end{array}$ & $\begin{array}{l}2 \mathrm{~m} \\
\text { little snow cover }\end{array}$ & $\begin{array}{l}2 \mathrm{~m} \\
\text { snow cover }\end{array}$ & $\begin{array}{l}3 \mathrm{~m} \\
\text { heavy snow cover }\end{array}$ & $\begin{array}{l}3 \mathrm{~m} \\
\text { heavy snow cover }\end{array}$ \\
\hline $\begin{array}{l}\text { Maximum } \\
\text { ice-free period }\end{array}$ & $\begin{array}{l}\text { Dec-Apr } \\
\text { every year }\end{array}$ & $\begin{array}{l}\text { Jan/Feb-Mar } \\
\text { every year }\end{array}$ & $\begin{array}{l}\text { Mar } \\
\text { most years }\end{array}$ & $\begin{array}{l}\text { Mar } \\
\text { not every year }\end{array}$ \\
\hline $\begin{array}{l}\text { Primary production } \\
\text { Phytoplankton } \\
\text { Sea ice algae } \\
\text { Benthic macroalgae } \\
\text { Benthic microalgae } \\
\left(\mathrm{g} \mathrm{C} \mathrm{m}^{-2} \mathrm{yr}^{-1}\right)\end{array}$ & $\begin{array}{l}44-100 \\
12 \\
\text { No data } \\
\pm 32^{\mathrm{b}}\end{array}$ & $\begin{array}{l}44-100 \\
<12 \\
\text { No data } \\
\pm 12^{b}\end{array}$ & $\begin{array}{l}\text { No data } \\
\text { No data } \\
\text { No data } \\
\text { No data }\end{array}$ & $\begin{array}{l}22-50^{\mathrm{a}} \\
\text { No data } \\
\text { No data } \\
\pm 4^{\mathrm{b}}\end{array}$ \\
\hline $\begin{array}{l}\text { Sedimentation } \\
\qquad\left(\mathrm{g} \mathrm{C} \mathrm{m}^{-2} \mathrm{yr}^{-1}\right)\end{array}$ & 21 & 21 & No data & 6 \\
\hline $\begin{array}{l}\text { Sampling site } \\
\text { Depth (m) } \\
\text { Slope } \\
\text { Sediments } \\
\text { Seal faeces }\end{array}$ & $\begin{array}{l}6-8 \\
45^{\circ} \\
\text { sand \& gravel } \\
\text { abundant }\end{array}$ & $\begin{array}{l}15-18 \\
10-25^{\circ} \\
\text { mud \& gravel } \\
\text { abundant }\end{array}$ & $\begin{array}{l}15-20 \\
45^{\circ} \\
\text { cobbles } \\
\text { very rare }\end{array}$ & $\begin{array}{l}20 \\
10-25^{\circ} \\
\text { mud \& silt } \\
\text { none }\end{array}$ \\
\hline $\begin{array}{l}\text { Benthos } \\
\text { Microalgae } \\
\left(\mathrm{g} \mathrm{C} \mathrm{m}^{-2}\right)\end{array}$ & $7.7-24.0$ & $4.1-8.6$ & No data & $0.5-3.8$ \\
\hline Macroalgae & $\begin{array}{l}\text { dense stands } \\
\text { in } 3.5 \mathrm{~m} \& \\
\text { below } 12 \mathrm{~m} \text { depth }\end{array}$ & $\begin{array}{l}\text { distinctly less } \\
\text { abundant than } \\
\text { at Cape Evans }\end{array}$ & $\begin{array}{l}\text { distinctly less } \\
\text { abundant than } \\
\text { at Cape Evans }\end{array}$ & very rare \\
\hline \multicolumn{5}{|l|}{ Zoobenthos } \\
\hline & No data & $\begin{array}{l}120000 \\
(20-40 \mathrm{~m} \text { depth })\end{array}$ & No data & $\begin{array}{l}10000 \\
(20-40 \mathrm{~m} \text { depth })\end{array}$ \\
\hline Dominant taxa & $\begin{array}{l}\text { Nemertini, } \\
\text { Echinoidea, } \\
\text { Gastropoda, } \\
\text { Asteroidea, }\end{array}$ & $\begin{array}{l}\text { Cnidaria, } \\
\text { Nemertini, } \\
\text { Polychaeta, } \\
\text { Bivalvia, } \\
\text { Gastropoda, } \\
\text { Echinoidea, } \\
\text { Asteroidea, }\end{array}$ & $\begin{array}{l}\text { Cnidaria, } \\
\text { Pygnogonida, } \\
\text { Ophiuroidea }\end{array}$ & $\begin{array}{l}\text { Ophiuroidea, } \\
\text { Crinoidea, } \\
\text { Echinoidea, } \\
\text { Asteroidea, } \\
\text { Bivalvia }\end{array}$ \\
\hline
\end{tabular}

${ }^{a}$ Estimate based on biomass differences between western and eastern Sound

${ }^{\mathrm{b}}$ Minimum estimates of Knox (1990)

${ }^{c}$ In austral summer measured from the tip to the upper inner edge. The position of the tetracycline mark was determined using a $350 \mathrm{~nm}$ UV-B lamp. To analyze natural growth bands, jaws were ground smooth to a thickness of $\leq 1 \mathrm{~mm}$ (Brey 1991), submerged in tert-butyl-methyl-ether and examined using a stereo microscope.

Tetracycline growth bands of individuals from McMurdo Station were treated as size-increment data (SID), i.e. data pairs of size $S_{1}$ at time of tagging $t_{1}$ and size $S_{2}$ at time of recapture $t_{2}$ (one year later). Natural growth band readings were treated as size-at-age data (SAD). The hypothesis that natural growth bands are produced annually was tested by comparing growth curves derived from SID and SAD based on the same set of specimens. Asymptotic size $\left(\mathrm{S}_{\infty}\right)$ and the growth constant $(\mathrm{K})$ of the Gompertz growth function,

$\mathrm{S}_{t}=\mathrm{S}_{\infty} \times \mathrm{e}^{-\mathrm{e}^{-K\left(t-t_{0}\right)}}$

which was algebraically re-arranged for use with SID

$\ln \left(\mathrm{S}_{2}\right)=\ln \left(\mathrm{S}_{\infty}\right) \times\left(1-\mathrm{e}^{-\mathrm{K}\left(t_{2}-t_{1}\right)}\right)+\ln \left(\mathrm{S}_{1}\right) \times\left(\mathrm{e}^{-\mathrm{K}\left(t_{2}-t_{1}\right)}\right)$,

were estimated using the SIMPLEX algorithm (see Press et al. 1986).
In all the other cases, the general growth model of Schnute (1981) was employed to establish growth functions:

$\mathrm{S}_{t}=\left\{\mathrm{Y}_{1}^{\mathrm{B}}+\left(\mathrm{Y}_{2}^{\mathrm{B}}-\mathrm{Y}_{1}^{\mathrm{B}}\right) \times\left[\frac{1-\mathrm{e}^{-\mathrm{A}\left(t-\tau_{1}\right)}}{1-\mathrm{e}^{-\mathrm{A}\left(\tau_{2}-\tau_{1}\right)}}\right]\right\} 1 / \mathrm{B}$.

The model includes four parameters, two constants A (time $\left.{ }^{-1}\right)$ and $\mathrm{B}$ (dimensionless) and the size $\mathrm{Y}_{1}$ and $\mathrm{Y}_{2}$. The two age values $\tau_{1}, \tau_{2}$ are chosen by the user, e.g. youngest and oldest individual in sample. The starting values of $Y_{1}$ and $Y_{2}$ are set accordingly. Special cases of this general model resemble historical growth models such as the von Bertalanffy, Richards, or Gompertz models.

Differences in growth among different sites were checked by analysis of variance of the residuals of the common growth function.

Productivity and production

Somatic production was computed by the mass-specific growth rate method according to Crisp (1984) from (i) the size-frequency 
distribution, (ii) the size-growth function and (iii) the size-body mass relation derived from $C$. Evans specimens. Production per "total catch" $\mathrm{P}_{\mathrm{S}}$ was computed by:

$\mathrm{P}_{\mathrm{S}}=\sum N_{\mathrm{i}} \times \mathrm{M}_{\mathrm{i}} \times \mathrm{G}_{\mathrm{i}}$,

where $N_{\mathrm{i}}$ is the number of individuals in size class $\mathrm{i}, \mathrm{M}_{\mathrm{i}}$ is the mean individual body mass in size class $\mathrm{i}$, and $\mathrm{G}_{\mathrm{i}}$ is the corresponding annual mass-specific growth rate, computed by:

$G_{i}=b \times\left(1 / S_{i}\right) \times(A / B) \times S_{i}^{1-B} \times\left[Y_{1}^{B}-\frac{Y_{2}^{B}-Y_{1}^{B}}{e^{-A\left(\tau_{2}-\tau_{1}\right)}}-S_{i}^{B}\right]$

$b$ is the slope of the size-mass regression (see below), $S_{i}$ is mean size in size class $i$ and $A, B, Y_{1}, Y_{2}, \tau_{1}$ and $\tau_{2}$ are parameters of Schnute's generalized growth model (Eq. 3).

Gonad mass was computed from the size-frequency distribution and the size-gonad mass relation established at $\mathrm{C}$. Evans, which was used for all sites. Gonad production was computed from abundance, gonad mass and an annual gonad output of $60 \%$ of maximum gonad mass (see Pearse and Giese 1966):

$\mathrm{P}_{\mathrm{G}}=\sum N_{\mathrm{i}} \times \mathrm{M}_{\mathrm{G}, \mathrm{i}} \times 0.6$.

The annual somatic production/biomass ratio $\mathrm{P}_{\mathrm{S}} / \mathrm{B}_{\mathrm{S}}$ was calculated from production $\mathrm{P}_{\mathrm{S}}$ and somatic biomass per total catch $\mathbf{B}_{\mathrm{S}}$ :

$\mathbf{B}_{\mathrm{S}}=\sum N_{\mathrm{i}} \times \mathrm{M}_{\mathrm{i}}$,

and total biomass was computed by:

$\mathrm{B}=\mathrm{B}_{\mathrm{S}}+\mathrm{B}_{\mathrm{G}}=\mathbf{B}_{\mathrm{S}}+\sum N_{\mathrm{i}} \times \mathrm{M}_{\mathrm{G}, \mathrm{i}}$.

Annual production of Sterechinus neumayeri per square meter was computed by multiplying the $\mathrm{P} / \mathrm{B}$ ratio with an estimate of average biomass derived from mean body mass per total catch $\mathrm{M}_{\text {mean }}$ and abundance counts in the field, $N_{\text {field }}$ :

$\mathbf{P}=\mathrm{P} / \mathrm{B} \times \mathrm{M}_{\text {mean }} \times N_{\text {field }}\left[\mathrm{g} \mathrm{m}^{-2} \mathrm{yr}^{-1}\right]$.

Dry mass (DM) was converted to ash free dry mass (AFDM) by the following factors (Brey unpublished)

Body: $\mathrm{AFDM}=0.13 \times \mathrm{DM}$

Gonads: AFDM $=0.90 \times \mathrm{DM}$

\section{Results}

\section{Morphometrics}

Mean jaw size/test diameter ratio varied between 0.200 (McMurdo Station free ranging specimens) and 0.247
(E. C. Armitage). The ratio was significantly different between all sites except between C. Evans and New Harbor (Table 2), no difference was found between caged and free ranging specimens at McMurdo Station. Therefore three different regression lines were fitted for the jaw size-test diameter relation (Fig. 2).

At C. Evans the relations between dry mass (DM) and test diameter (D) were found to be

Somatic: $\log (\mathrm{g} \mathrm{DM})=-3.804+2.769 \times \log (\mathrm{mm} \mathrm{D})$; $N=40 ; r^{2}=0.944$

Gonad: $\log (\mathrm{g} \mathrm{DM})=-5.510+3.497 \times \log (\mathrm{mm} \mathrm{D})$; $N=40 ; r^{2}=0.817$.

No significant differences in intercept or slope $(\alpha=0.05)$ were found between the regressions for male $(N=15)$ and female $(N=25)$ individuals.

\section{Abundance and size distribution}

In 1991, mean abundance of Sterechinus neumayeri in the 20 to $25 \mathrm{~m}$ depth range was found to be 0.40 ind $\mathrm{m}^{-2}(\mathrm{SD}=0.10)$ at McMurdo Station and 0.77 ind $\mathrm{m}^{-2}(\mathrm{SD}=0.21)$ at C. Evans. In 1993 average abundance at $\mathrm{C}$. Evans was 2.70 ind $\mathrm{m}^{-2}(\mathrm{SD}=2.30)$ between 3 and $21 \mathrm{~m}$ water depth $(0.6,1.4,1.0,6.6,4.9$, 3.3 and 1.2 ind $\mathrm{m}^{-2}$ in $3,6,9,12,15,18$ and $21 \mathrm{~m}$ depth, respectively). At both stations the majority of individuals $(68 \%$ at McMurdo Station and $95 \%$ at C. Evans) ranged between 40 and $60 \mathrm{~mm}$ in diameter (Fig. 3). No specimens $<30 \mathrm{~mm}$ diameter were found. At New Harbor, mean abundance was computed to be 0.27 ind $\mathrm{m}^{-2}(\mathrm{SD}=0.12)$ in 1991 . The 16 specimens collected ranged from 45 to $68 \mathrm{~mm}$ in diameter (mean $=56.5, \mathrm{SD}=6.7)$. No abundance estimates were made at E. C. Armitage. However, during the 1991 sampling only seven specimens were found, despite the same diving time as at New Harbor and a much more careful search for sea urchins. The specimens collected from this site were also distinctly smaller, ranging from 28 to $39 \mathrm{~mm}$ in diameter $($ mean $=31.9, \mathrm{SD}=3.8$ ).
Table 2 Sterechinus neumayeri. Analysis of variance (ANOVA) of differences in the jaw size/test diameter $(J / D)$ ratio among sites and Bonferroni/Dunn post-hoc test on differences between means

\begin{tabular}{|c|c|c|c|c|c|c|}
\hline $\begin{array}{l}\text { ANOVA, } \\
\text { Source }\end{array}$ & $d f$ & SS & MS & $F$ & $P$ & \\
\hline Site & 4 & 0.028 & 0.007 & 23.037 & $<0.001$ & \\
\hline Residual & 228 & 0.071 & 0.0003 & & & \\
\hline \multirow{2}{*}{$\begin{array}{l}\text { Bonferroni/Dunn, } \\
\text { Site }\end{array}$} & & & & & & \\
\hline & Mean $J / D$ & $\mathrm{SD}$ & McM. free & C. Evans & N. Harbor & E.C. Armitage \\
\hline McMurdo caged & 0.205 & 0.017 & - & $*$ & $*$ & $*$ \\
\hline McMurdo free & 0.200 & 0.018 & & $*$ & $*$ & * \\
\hline C. Evans & 0.219 & 0.019 & & & - & * \\
\hline New Harbor & 0.219 & 0.011 & & & & $*$ \\
\hline E.C. Armitage & 0.247 & 0.014 & & & & \\
\hline
\end{tabular}

* Significant difference at $\alpha=0.05 ;$ - no significant difference 


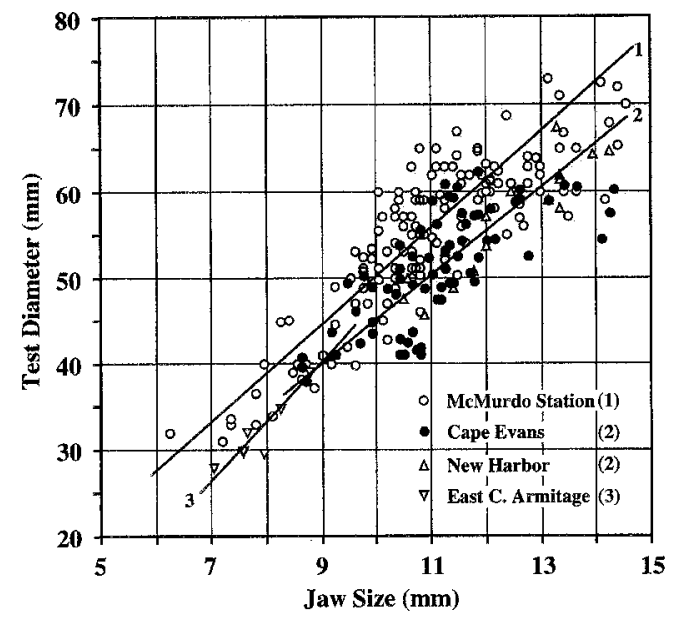

Fig. 2 Sterechinus neumayeri. Regression between test diameter $\mathrm{D}(\mathrm{mm})$ and jaw size $\mathrm{J}(\mathrm{mm})$, geometric mean regression model according to Ricker (1973). McMurdo Station: $\mathrm{D}=-6.149+$ $5.565 \times \mathrm{J} ; N=137, r^{2}=0.748$; Cape Evans and New Harbor: $\mathrm{D}=-6.865+5.185 \times \mathrm{J} ; \quad N=89, \quad r^{2}=0.629 ; \quad$ Cape Armitage: $\mathrm{D}=-22.121+6.892 \times \mathrm{J} ; N=7, r^{2}=0.844$

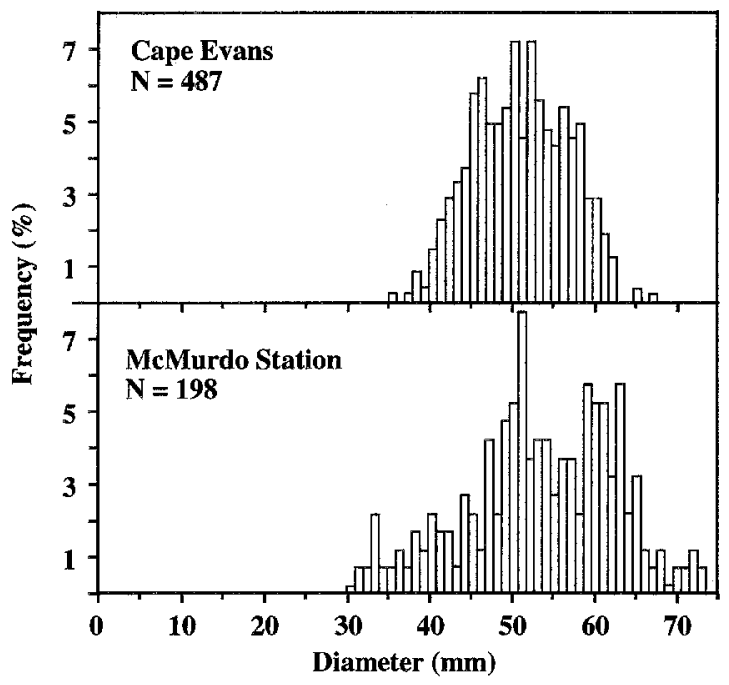

Fig. 3 Sterechinus neumayeri. Size-frequency distribution at Cape Evans in December 1992 and at McMurdo Station in December (composed of the 130 specimens collected in 1990 and 68 specimens collected in 1989 and remaining from laboratory experiments)

\section{Growth}

Natural growth lines in the jaws consisted of alternating opaque zones (light in reflected light, dark in transmitted light) and translucent zones (dark in reflected light, light in transmitted light, Fig. 4), as observed in other parts of echinoid skeletons by Pearse and Pearse (1975) and others. On the leading edge of most jaws a very narrow opaque zone was visible, preceded by alternating broader translucent and opaque zones. The tetracycline marks were clearly visible in the UV light as distinct green lines in 59 of the 60 tagged individuals. The mark was situated at the transition from the second to last translucent zone to the following opaque zone (Fig. 4b, c). One specimen showed a very weak and less distinct mark and was excluded from further analysis.

\section{Evaluation of natural growth line formation}

The 59 specimens recovered from McMurdo Station that showed distinct tetracycline labels were used to compare growth estimates based on tagging-recapture data and natural growth line counts. The size-increment data were fitted best by a Gompertz growth function

$\mathrm{J}_{t}=14.02 \mathrm{~mm} \times \mathrm{e}^{-\mathrm{e}^{-0.107 t}} ; \mathrm{R}^{2}=0.994$.

No significant difference $(P=0.129)$ was found between caged and free ranging specimens. The function fitted to size-at-age data derived from natural growth line readings of the same 59 specimens was very similar

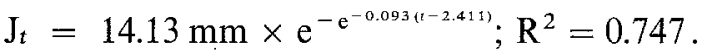

Individual age inferred from this function is linearly related to age inferred from the above growth function based on size-increment data. The slope of the regression does not differ significantly from $1.0(\alpha=0.05$; Fig. 5), indicating natural growth lines are formed annually.

\section{Size-at-age data from all sites}

Natural growth lines were counted in 83 specimens from McMurdo Station, 73 specimens from C. Evans, 16 specimens from New Harbor and 7 specimens from E. C. Armitage. Schnute's generalized growth model was fitted to these 179 data pairs of jaw size J-at-age data as well as test diameter S-at-age data (Fig. 6). The resulting growth curves corresponded to generalized von Bertalanffy functions (Table 3 )

$$
\begin{aligned}
& \mathrm{J}_{t}=30.98 \mathrm{~mm} \times\left[1-\mathrm{e}^{-0.001(t-1.628)}\right]^{0.238} \\
& \mathrm{~S}_{t}=70.23 \mathrm{~mm} \times\left[1-\mathrm{e}^{-0.031(t-1.651)}\right]^{0.267} .
\end{aligned}
$$

A subsequent analysis of the residuals of the jaw size growth functions showed significant differences between E. C. Armitage and the other three sites (Table 4), whereas the residuals of the test diameter growth function also showed a significant difference between McMurdo Station and C. Evans and New Harbor (Table 5). Consequently, the test diameter growth functions fitted separately to the data from McMurdo Station (generalized von Bertalanffy function)

$\mathrm{S}_{t}=68.17 \mathrm{~mm} \times\left[1-\mathrm{e}^{-0.100(t+2.481)}\right]^{0.880}$ 

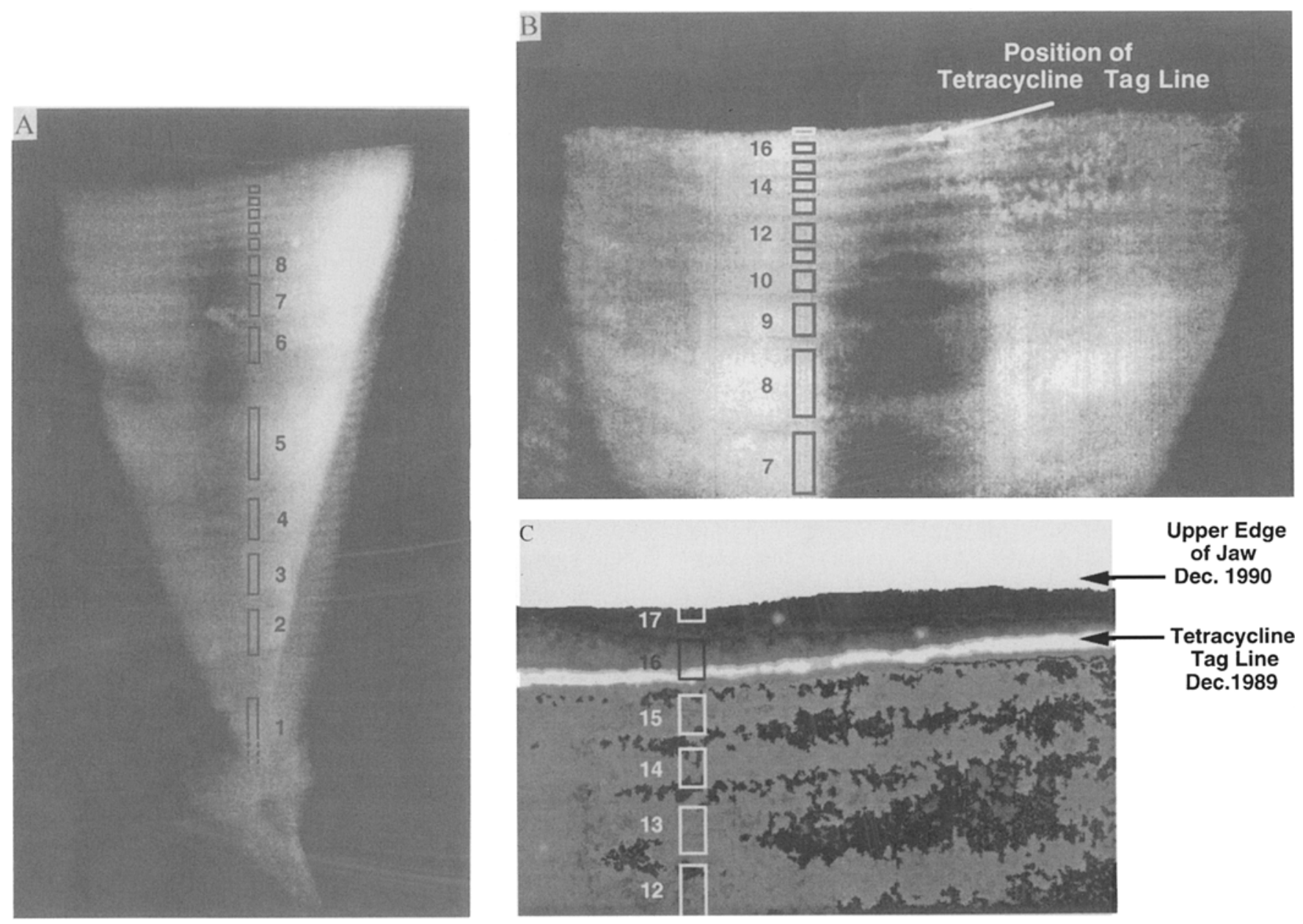

Fig. 4 Sterechinus neumayeri. Growth bands in the jaw. Tetracycline labelled free ranging specimen from McMurdo Station (test diameter $62.0 \mathrm{~mm}$, jaw size $11.9 \mathrm{~mm}, 17$ growth bands). Photographs taken by either stereo microscope or compound microscope and subsequently digitized. A View of total jaw in reflected light. Zones of rapid growth appear light. Bars indicate the first 13 growth bands. The unusual width of light band No. 5 and the subsequent dark band may indicate a difficult to identify intermittent growth band. B Enlarged view of upper jaw edge. Original photograph was taken in transmitting light, but was electronically inverted, i.e. zones of rapid growth appear light. Brightness, brilliance and contrast have been modified to show most recent growth lines. Arrow indicates tetracycline tag line running parallel to the natural dark growth line. C Detailed microscopic view $(\times 100)$ of upper jaw edge in reflected UV light. Brightness, brilliance and contrast have been modified to show both the tetracycline label (bright line) and preceding natural growth lines

and from C. Evans and New Harbor (Richards function)

$\mathrm{S}_{t}=66.49 \times\left[1-(1 /-0.446) \times \mathrm{e}^{-0.072(t-2.597)}\right]^{-0.446}$

were distinctly different (Fig. 7). The limited number and range of data did not allow for the computation of a separate growth curve for E. C. Armitage.

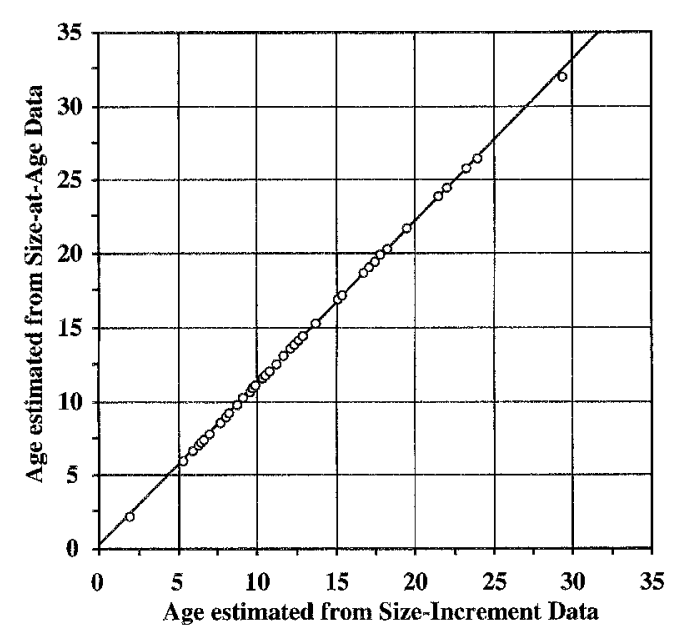

Fig. 5 Sterechinus neumayeri. Relation between age estimated from size-at-age data (SAD, natural growth band counts) and age estimated from size-increment data (SID, tetracycline tagging) at McMurdo Station. $\mathrm{Age}_{\mathrm{SID}}$ and $\mathrm{Age}_{\mathrm{SAD}}$ were computed from size $\mathrm{J}_{t}$ using Gompertz growth functions fitted to the size-increment data and to the size-at-age data (setting $t_{0}$ from 2.411 to zero for comparability), respectively. SID: $\mathrm{J}_{t}=14.02 \mathrm{~mm} \times \mathrm{e}^{-\mathrm{e}^{-0.1077}}$; SAD: $\mathbf{J}_{t}=14.13 \mathrm{~mm} \times \mathrm{e}^{-\mathrm{e}^{-0.093 t}} ;$ Age $_{\mathrm{SAD}}=0.243+1.098 \quad \mathrm{Age}_{\mathrm{SID}}$; $N=57 ; r^{2}=0.999$. Two of the 59 tagged specimens are not included in the regression because $J_{t}>J_{\infty}$ for one or both growth functions 


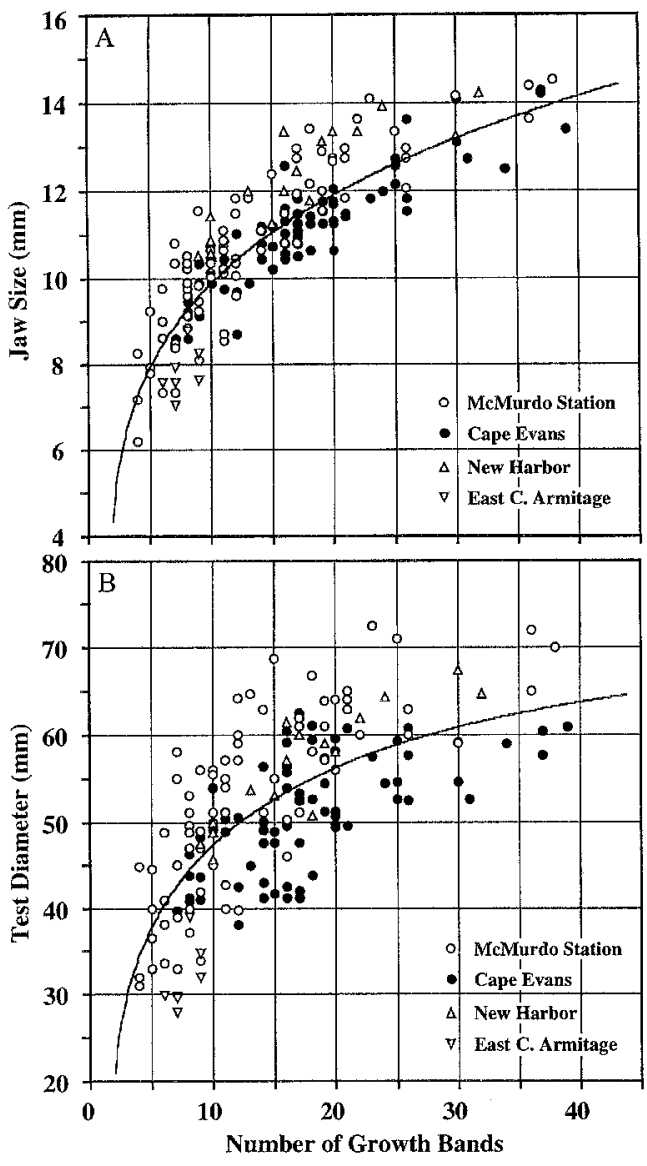

Fig. 6 Sterechinus neumayeri. Schnute's growth model fitted to 179 size-at-age data pairs. A Size = Jaw size: generalized von Bertalanffy function, $\mathrm{J}_{t}=30.98 \mathrm{~mm} \times\left(1-\mathrm{e}^{-0.001\left(t^{-1.628)}\right.}\right)^{0.238} ; \mathbf{B}$ Size $=$ Test diameter: generalized von Bertalanffy function, $D_{t}=70.23 \mathrm{~mm} \times$ $\left(1-\mathrm{e}^{-0.031(t-1.651)}\right)^{0.267}$

\section{Productivity and production}

\section{Individual production}

The relation between test diameter and individual production of Sterechinus neumayeri is shown in Fig. 8A (DM) and B (AFDM). Somatic production increased with diameter up to 43 and $52 \mathrm{~mm}$ at McMurdo Station and C. Evans and New Harbor, respectively, and then decreased again. At McMurdo Station the slope of this curve was much steeper, and the maximum was about 2.6 times higher than at C. Evans and New Harbor. Gonad production increased exponentially with increasing diameter. In terms of AFDM, gonad production exceeded peak somatic production by factors of 5.7 (McMurdo Station, $43 \mathrm{~mm}$ size class) and 36.7 (C. Evans and New Harbor, $52 \mathrm{~mm}$ size class).

\section{Population production}

At McMurdo Station, the annual $\mathrm{P} / \mathrm{B}$ ratio was 0.208 and 0.450 when based on DM and AFDM, respectively

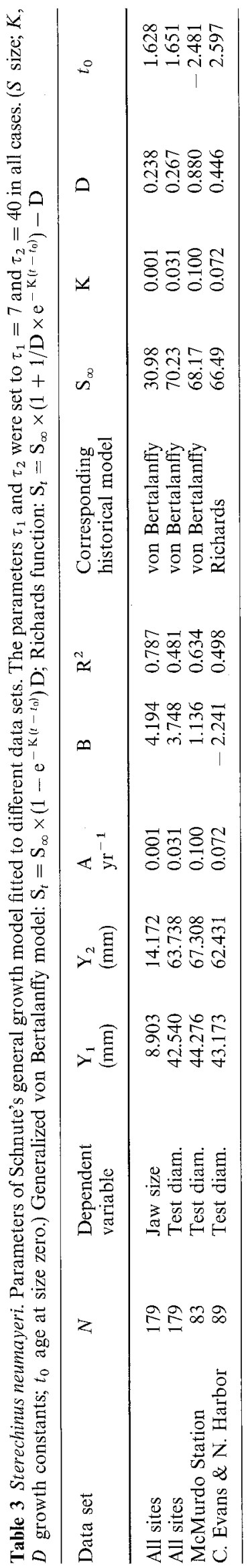


Table 4 Sterechinus neumayeri. Growth of jaw: analysis of variance $(A N O V A)$ of differences in the residuals of the common growth function among sites and Bonferroni/

Dunn post-hoc test on differences between means

\begin{tabular}{|c|c|c|c|c|c|}
\hline $\begin{array}{l}\text { ANOVA, } \\
\text { Source }\end{array}$ & $d f$ & $\mathrm{SS}$ & MS & $F$ & $P$ \\
\hline Site & 3 & 29.847 & 9.949 & 19.965 & $<0.001$ \\
\hline Residual & 175 & 87.207 & 0.499 & & \\
\hline $\begin{array}{l}\text { Bonferroni/Dunn, } \\
\text { Site }\end{array}$ & Mean Residual & C. Evans & N. Harbor & E. C. Armit. & \\
\hline McMurdo Stat. & 0.205 & - & - & $*$ & \\
\hline C. Evans & 0.219 & & - & $*$ & \\
\hline New Harbor & 0.219 & & & $*$ & \\
\hline E.C. Armitage & 0.247 & & & & \\
\hline
\end{tabular}

* Significant difference at $\alpha=0.05$; - no significant difference
Table 5 Sterechinus neumayeri. Growth of test: analysis of variance $(A N O V A)$ of differences in the residuals of the common growth function among sites and Bonferroni

Dunn post-hoc test on differences between means

\begin{tabular}{|c|c|c|c|c|c|}
\hline $\begin{array}{l}\text { ANOVA, } \\
\text { Source }\end{array}$ & $d f$ & SS & MS & $F$ & $P$ \\
\hline Site & 3 & 2230.524 & 910.175 & 27.128 & $<0.001$ \\
\hline Residual & 175 & 5871.446 & 33.551 & & \\
\hline $\begin{array}{l}\text { Bonferroni/Dunn, } \\
\text { Site }\end{array}$ & Mean Residual & C. Evans & N. Harbor & E. C. Armit. & \\
\hline McMurdo Stat. & 3.595 & $*$ & $*$ & $*$ & \\
\hline C. Evans & -2.457 & & - & $*$ & \\
\hline New Harbor & -1.793 & & & $*$ & \\
\hline E.C. Armitage & -12.906 & & & & \\
\hline
\end{tabular}

* Significant difference at $\alpha=0.05$; - no significant difference

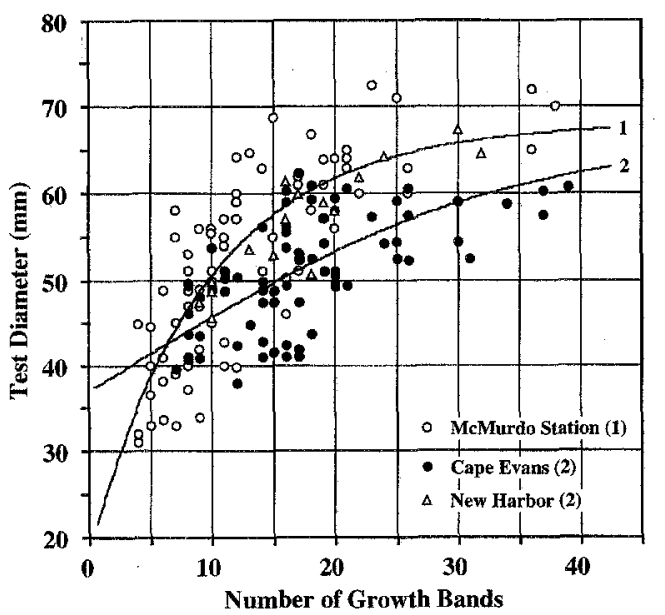

Fig. 7 Sterechinus neumayeri. Schnute's growth model fitted to 83 diameter-at-age data pairs from McMurdo Station and to 89 diameter-at-age data pairs from C. Evans and New Harbor. McMurdo Station: generalized von Bertalanffy function, $S_{t}=68.17 \mathrm{~mm} \times\left(1-\mathrm{e}^{-0.100(t+2.481)}\right)^{0.880} ;$ C. Evans and New Harbor: Richards function, $S_{t}=66.49 \times\left(1+1 / \mathrm{D} \times \mathrm{e}^{-0.072(t-2.597)}\right)^{-0.449}$ (Open circles McMurdo Station; filled circles $\mathrm{C}$. Evans; open triangles New Harbor)

Fig. 8 Sterechinus neumayeri. Relation between test diameter and individual production at McMurdo Station and C. Evans (also New Harbor). A Dry mass $(D M)$, B ash free dry mass (AFDM). (Open circles somatic production at McMurdo Station; filled circles somatic production at $\mathrm{C}$. Evans; open squares gonad production at both stations)

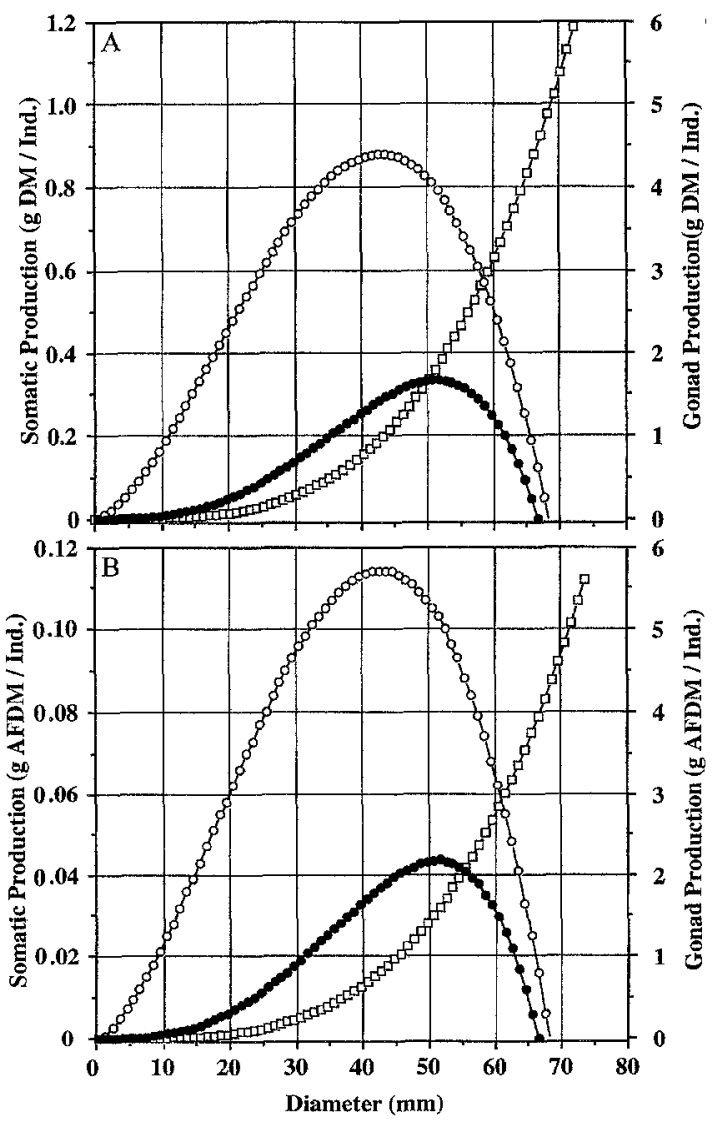


(Table 6). Total production amounted to $1.19 \mathrm{~g} \mathrm{DM}$ $\mathrm{m}^{-2} \mathrm{yr}^{-1}\left(0.88 \mathrm{~g} \mathrm{AFDM} \mathrm{m}^{-2} \mathrm{yr}^{-1}\right)$. 79\% (DM) or $96 \%$ (AFDM) of this total was comprised of gonad production. At $\mathrm{C}$. Evans, the annual $\mathrm{P} / \mathrm{B}$ ratio was slightly lower, 0.183 (DM) and 0.436 (AFDM), respectively (Table 6). Because of the higher abundance, total production was much higher at this site, $3.01 \mathrm{~g} \mathrm{DM}$ $\mathrm{m}^{-2} \mathrm{yr}^{-1}\left(2.40 \mathrm{~g} \mathrm{AFDM} \mathrm{m}^{-2} \mathrm{yr}^{-1}\right)$ in 6 to $8 \mathrm{~m}$ depth and $5.86 \mathrm{~g} \mathrm{DM} \mathrm{m}^{-2} \mathrm{yr}^{-1}$ (4.63 $\mathrm{g} \mathrm{AFDM} \mathrm{m}^{-2} \mathrm{yr}^{-1}$ ) for the whole depth range ( 3 to $21 \mathrm{~m}$ ). $86 \%$ (DM) or $98 \%$ (AFDM) of this total was comprised of gonad production. At New Harbor, the annual $\mathrm{P} / \mathrm{B}$ ratio was estimated to be 0.182 (DM) and 0.436 (AFDM), whereas production was estimated to be $0.78 \mathrm{~g} \mathrm{DM}$ $\mathrm{m}^{-2} \mathrm{yr}^{-1}\left(0.65 \mathrm{~g} \mathrm{AFDM} \mathrm{m}^{-2} \mathrm{yr}^{-1}\right)$.

For E. C. Armitage, insufficient data do not allow estimates of productivity and production, but the low growth rate (Table 6), the small average size (Fig. 6) and the very low abundance should result in population production values much lower than at the other sites.

\section{Discussion}

Growth band formation

Patterns of alternating translucent and opaque zones in skeletal elements of echinoids have been reported for many species (Birkeland and Chia 1971; Miller and Mann 1973; Crapp and Wills 1975; Pearse and Pearse 1975; Gage and Tyler 1985; Gage 1992 and others). However, feeding experiments showed that these bands are not necessarily formed annually (Pearse and Pearse 1975). Only in a few cases an annual rhythm of band formation could be demonstrated by controlled growth experiments in aquaria (Miller and Mann 1973) or by labelling experiments (Gage 1992). The similarity of growth parameter values and of age estimates derived from size-increment data and from natural growth bands in Sterechinus neumayeri at McMurdo Station (Fig. 5) provide some of the most convincing data indicating annual formation of growth bands in any echinoid. Such annual patterns might be expected for an environment with extreme seasonal variation.

The position of the tetracycline mark at the transition from the second to last translucent to the subsequent opaque zone (Fig. 4b, c) indicates that two growth bands are formed per year. These are comprised of a translucent band formed before December and an opaque band formed after December. Pearse and Pearse (1975) found translucent bands to be formed during periods of slow growth, and opaque bands during periods of rapid growth. Therefore, Sterechinus neumayeri seems to grow slowly during the austral winter/spring until December and then rapidly during the austral summer/fall. The narrow opaque band observed at the edge of most jaws indicates rapid growth initiated slightly before sampling in December. Onset of growth may be triggered by the influx of phytoplankton into McMurdo Sound, beginning at the end of November (Knox 1990; Rivkin 1991). Alternatively, it could be a response to increasing photoperiod. Pearse et al. (1986) found in a temperate sea urchin that somatic growth was enhanced, and gametogenesis suppressed during increasing day-lengths. In $S$. neumayeri
Table 6 Sterechinus neumayeri. Productivity and production at McMurdo Station (20 to $25 \mathrm{~m}$ ), C. Evans $(6$ to $8 \mathrm{~m})$ and New Harbor ( 20 to $25 \mathrm{~m})$. ( $N$ abundance; $M$ mean body mass; $S$ somatic; $G$ gonad; $D M$ dry mass; $A F D M$ ash free dry mass). Conversion factors (Brey unpublished-Body: AFDM = $0.13 \times$ DM; Gonads: AFDM $=$ $0.90 \times \mathrm{DM}$

\begin{tabular}{|c|c|c|c|c|c|c|}
\hline & \multicolumn{2}{|c|}{ McMurdo Station } & \multicolumn{2}{|c|}{ Cape Evans ${ }^{b}$} & \multicolumn{2}{|c|}{ New Harbor } \\
\hline & $\mathrm{DM}$ & AFDM & DM & AFDM & $\mathrm{DM}$ & AFDM \\
\hline $\mathrm{P}_{\mathrm{S}} / \mathrm{B}_{\mathrm{S}}\left(\mathrm{yr}^{-1}\right)$ & 0.060 & 0.060 & 0.035 & 0.035 & 0.021 & 0.021 \\
\hline $\mathrm{P}_{G} / \mathrm{B}_{G}\left(\mathrm{yr}^{-1}\right)^{\mathrm{a}}$ & 0.600 & 0.600 & 0.600 & 0.600 & 0.600 & 0.600 \\
\hline $\mathrm{P} / \mathrm{B}\left(\mathrm{yr}^{-1}\right)$ & 0.208 & 0.450 & 0.183 & 0.436 & 0.181 & 0.441 \\
\hline mean $N\left(\mathrm{~m}^{-2}\right)$ & 0.40 & 0.40 & 1.40 & 1.40 & 0.27 & 0.27 \\
\hline mean $\mathrm{M}_{\mathrm{S}}(\mathrm{g})$ & 10.405 & 1.353 & 8.769 & 1.140 & 11.553 & 1.502 \\
\hline mean $\mathrm{M}_{\mathrm{G}}(\mathrm{g})$ & $3.904^{c}$ & $3.514^{c}$ & 3.103 & 2.793 & $4.397^{\mathrm{c}}$ & $3.959^{\mathrm{c}}$ \\
\hline mean $\mathrm{M}(\mathrm{g})$ & 14.309 & 4.867 & 11.872 & 3.932 & 15.950 & 5.460 \\
\hline $\mathrm{B}_{\mathrm{S}}\left(\mathrm{g} \mathrm{m}^{-2}\right)$ & 4.162 & 0.541 & 12.276 & 1.596 & 3.119 & 0.406 \\
\hline $\mathrm{B}_{\mathrm{G}}\left(\mathrm{g} \mathrm{m}^{-2}\right)$ & $1.562^{\mathrm{c}}$ & $1.406^{\mathrm{c}}$ & 4.344 & 3.910 & $1.187^{\mathrm{c}}$ & $1.069^{\mathrm{c}}$ \\
\hline $\mathrm{B}\left(\mathrm{g} \mathrm{m}^{-2}\right)$ & 5.724 & 1.947 & 16.620 & 5.505 & 4.307 & 1.474 \\
\hline $\mathrm{P}_{\mathrm{S}}\left(\mathrm{g} \mathrm{m}^{-2} \mathrm{yr}^{-1}\right)$ & 0.250 & 0.033 & 0.430 & 0.056 & 0.065 & 0.009 \\
\hline$P_{G}\left(\mathrm{~g} \mathrm{~m}^{-2} \mathrm{yr}^{-1}\right)$ & $0.937^{\mathrm{c}}$ & $0.844^{\mathrm{c}}$ & 2.606 & 2.346 & $0.712^{\mathrm{c}}$ & $0.641^{\mathrm{c}}$ \\
\hline $\mathrm{P}\left(\mathrm{g} \mathrm{m}^{-2} \mathrm{yr}^{-1}\right)$ & 1.191 & 0.876 & 3.006 & 2.402 & 0.778 & 0.650 \\
\hline
\end{tabular}

${ }^{a}$ Gonad Production/Biomass ratio $\mathrm{P}_{\mathrm{S}} / \mathrm{B}_{\mathrm{S}}$ estimated from Pearse and Giese (1966)

${ }^{b}$ Production for the total depth range ( 3 to $25 \mathrm{~m}, N=2.7$ ind $\mathrm{m}^{-2}$ ) can be estimated by

$2.7 / 1.4 \times \mathrm{P}_{(6-8 \mathrm{~m})}$. Production in $20-25 \mathrm{~m}$ depth $\left(1.0\right.$ ind $\left.\mathrm{m}^{-2}\right)$ can be approximated by $0.7 \times \mathrm{P}_{(6-8 \mathrm{~m})}$

${ }^{\mathrm{c}}$ Based on size-gonad mass relation established at C. Evans 
gametogenesis occurs mainly in austral autumn/winter during decreasing or zero day-length, and spawning occurs in austral spring/summer during $24 \mathrm{~h}$ daylength (Pearse and Giese 1966; Yakovlew 1983; Pearse and Bosch 1991).

\section{Comparison among sites}

Differences in population dynamics of Sterechinus neumayeri among the four sites are assumed to be related mainly to differences in food availability, although other factors such as differences in interspecific competition and predation should be considered. Since $S$. neumayeri feeds mainly on benthic diatoms and organic benthic deposits, the highly productive sites on the eastern side of the Sound should provide the best living conditions (see Table 1). The shallow (6 to $8 \mathrm{~m}$ ) C. Evans site should allow for a higher microbenthic production than the deeper $(15$ to $18 \mathrm{~m})$ site at McMurdo Station. The dense macroalgal stocks at C. Evans (Miller and Pearse 1991), as well as the numerous seal faeces at McMurdo Station and C. Evans (L. Basch personal observations) may also improve food conditions. New Harbor on the western side of the Sound has lower levels of pelagic and microbenthic primary production (Dayton and Oliver 1977; Barry et al. 1994), while E. C. Armitage is assumed to provide the poorest conditions with coarse sediments indicative of strong currents and low sedimentation, and an almost permanent snow laden sea-ice cover that inhibits sea-ice and benthic microalgal primary production (McClintock et al. 1988).

Differences in the amount of food available will cause differences in production of Sterechinus neumayeri. Production $\left(\mathrm{g} \mathrm{m}^{-2} \mathrm{yr}^{-1}\right)$ depends primarily on two parameters, population size (abundance, biomass) and individual growth rate (somatic and gonad productivity). As discussed above, we should expect habitat-specific production in S. neumayeri to decrease according to the ranking C. Evans, McMurdo Station, New Harbor, E. C. Armitage. In the following sections we will evaluate this assumption and discuss the mode of "regulation" of production in response to different food levels in $S$. neumayeri.

\section{Abundance and biomass}

A comparatively high abundance and biomass of Sterechinus neumayeri was found in shallow water at C. Evans $\left(6 \mathrm{~m}\right.$ depth) with values of 1.4 ind $\mathrm{m}^{-2}$ and $5.51 \mathrm{~g} \mathrm{AFDM} \mathrm{m}^{-2}$. Even below $20 \mathrm{~m}$ depth (0.77 ind $\mathrm{m}^{-2}$ in 1990 and 1.20 ind $\mathrm{m}^{-2}$ in 1993) abundance was higher than at the other sites. Abundance and biomass of $S$. neumayeri at McMurdo Station at 20 to $25 \mathrm{~m}$ depth, 0.40 ind $\mathrm{m}^{-2}$ and $1.95 \mathrm{~g}$ AFDM $\mathrm{m}^{-2}$, is less than half the amount at C. Evans in the same depth range. Divers did not recognize any distinct differences in abundance between the 20 to $25 \mathrm{~m}$ depth and the shallower experimental site (15 to $18 \mathrm{~m}$ ) at McMurdo Station. The figures at New Harbor ( 20 to $25 \mathrm{~m}$ ), 0.27 ind $\mathrm{m}^{-2}$ and $1.47 \mathrm{~g} \mathrm{AFDM} \mathrm{m}^{-2}$, are slightly lower than at McMurdo Station, whereas at E. C. Armitage abundance was observed to be extremely low, and biomass would accordingly be low.

The ranking of abundance and biomass figures adheres to our proposed ranking of sites according to food level, suggesting that adaption to different food levels results in an "adjustment" of abundance and biomass in Sterechinus neumayeri. This sequence is paralleled by differences in abundance and nutritional condition of the common sea star Odontaster validus found by Pearse (1965) and McClintock et al. (1988). The exceptionally high values for $S$. neumayeri at C. Evans may be explained partially by higher than estimated microbenthic production (see below). Moreover, the abundant seal faeces (L. Basch personal observations) and macroalgal debris (Dearborn 1965; Pearse and Giese 1966) may be of more significance than thought previously, especially during periods when microbenthic standing stocks are low.

\section{Individual growth}

The validity of the growth curves computed for Sterechinus neumayeri suffers to a certain extent from the absence of smaller individuals. This is especially the case at C. Evans and New Harbor, where some urchins $<35 \mathrm{~mm}$ would have significantly altered the left portion of the growth functions. Nonetheless, it is unlikely that the addition of smaller individuals would distinctly change the shape of the growth functions which describe the present size range of individuals.

Among the four sites investigated, jaws and tests of Sterechinus neumayeri grew slowest at E.C. Armitage (Fig. 6, Tables 4 and 5), but the low number of specimens $(N=7)$ precluded the establishment of a separate growth curve. Growth, as measured in changes in jaw size, was not different among the remaining three sites, McMurdo Station, C. Evans and New Harbor (Table 4), but growth in test diameter was significantly higher at McMurdo Station (Table 5, Figs. 7 and 8). Interestingly, the jaw size/test diameter ratio (Table 2) is inversely related to test growth, and is lowest at McMurdo Station (mean: 0.201), intermediate at C. Evans and New Harbor (0.219) and highest at E. C. Armitage (0.247) (i.e. the slower the individuals grow, the larger is the jaw in relation to the test). There is evidence that both the differences in growth and the differences in jaw size/test diameter ratio are related to different food levels at the sites investigated. Ebert (1968) showed that growth in Strongylocentrotus purpuratus depends on the amount of food available, and Ebert (1980) as well as Levitan (1991) found the jaw 
size/test diameter ratio in two sea urchins, Strongylocentrotus purpuratus and Diadema antillarum, to be inversely related to food availability. Therefore, individual growth and jaw size/test diameter ratios indicate food conditions for S. neumayeri are best at McMurdo Station, intermediate at C. Evans and New Harbor, and worst at E. C. Armitage.

\section{Productivity and production}

At E. C. Armitage, the low abundance of Sterechinus neumayeri did not allow for computation of productivity ( $\mathrm{P} / \mathrm{B}$ ratio) and production $\left(\mathrm{g} \mathrm{m}^{-2} \mathrm{yr}^{-1}\right)$. However, it is obvious that, as with the asteroid Odontaster validus (McClintock et al. 1988), productivity, which is related to growth rate, is very low at E. C. Armitage. Low production is also reflected in the extremely low abundance and small average size of the individuals. The production computations for New Harbor should be interpreted cautiously, as they are based on a size-frequency distribution of only 16 individuals.

Provided the size-gonad mass relation established at C. Evans is valid for all sites, differences in productivity between C. Evans, McMurdo Station and New Harbor are slight; annual $\mathrm{P} / \mathrm{B}$ is $0.436,0.450$ and 0.441 (based on AFDM), respectively. However, production is distinctly higher at C. Evans (2.40 $\left.\mathrm{g} \mathrm{AFDM} \mathrm{m}^{-2} \mathrm{yr}^{-1}\right)$ than at McMurdo Station (0.88 $\mathrm{g} \mathrm{AFDM} \mathrm{m}^{-2} \mathrm{yr}^{-1}$ ) and New Harbor $\left(0.65 \mathrm{~g} \mathrm{AFDM} \mathrm{m}^{-2} \mathrm{yr}^{-1}\right.$, Table 6).

Population $\mathrm{P} / \mathrm{B}$ ratios show no clear ranking among sites with the one likely exception of E. C. Armitage. Production of Sterechinus neumayeri, however, shows a similar ranking to both abundance and biomass, with the sequence C. Evans $>$ McMurdo Station $>$ New Harbor $>$ E. C. Armitage.

In summary, food conditions seem to affect abundance and biomass of Sterechinus neumayeri more than individual growth rates, which are clearly affected only at the very poor E. C. Armitage site. Moreover, there is a contradiction between the number one ranking of the population at McMurdo Station according to individual growth and jaw size/test diameter ratios, while the population at $\mathrm{C}$. Evans had highest ranking according to abundance, biomass and production. This contradiction could be related to density-dependent intraspecific competition. The superior food conditions at C. Evans may increase recruitment success (but see below), or could constantly attract adult sea urchins to immigrate and remain in the area. Both processes would lead to increased abundance and subsequently to increased intraspecific competition for food. Hence, although absolute food supply per square meter is higher at C. Evans than at McMurdo Station, the lower amount of food per individual would cause decreased individual growth rates, as observed in other benthic invertebrates (see e.g. Peterson 1982, 1989).

\section{Reproduction and recruitment}

Sterechinus neumayeri reproduces by releasing large numbers of planktotrophic larvae (Bosch et al. 1987). Pearse and Giese (1966) calculated an average prespawning gonad index $(100 \times$ gonad mass/body mass $)$ of 32.5 between April and November (austral spring), and a decline to about 12 between December and February (austral summer) for $S$. neumayeri at C. Evans. The specimens we collected for gonad mass determination at $\mathrm{C}$. Evans $(4 \mathrm{Dec})$ had a gonad index of $34.6(\mathrm{SD}=10.2, N=40)$, indicative of a prespawning condition. Hence a gonad output of $60 \%$ of maximum gonad mass $[100 \times(32.5-12) / 32.5]$ is realistic.

The share of total production that is attributable to gonad production, $96 \%$ at McMurdo Station and $98 \%$ at C. Evans (in terms of AFDM), is extremely high compared to values available from boreal and subtropical echinoids, in which gonad production never exceeds $40 \%$ of total production (Table 7 ). Even in the Antarctic sea urchin Sterechinus antarcticus this figure is only $48 \%$ (recomputed from Brey 1991; see comment in Table 7). In contrast to the extremely high amount of energy directed into reproduction in $S$. neumayeri in McMurdo Sound, levels of successful recruitment seem to be quite low. The youngest specimens we found had an estimated age of $4 \mathrm{yr}$ at McMurdo Station, $6 \mathrm{yr}$ at

Table 7 Sterechinus neumayeri. Comparison of individual somatic $\left(P_{S}\right)$ and gonad production $\left(P_{G}\right)$ in $S$. neumayeri and other echinoid populations (g AFDM)

\begin{tabular}{llllll}
\hline Species & Area & $\mathrm{P}_{\mathrm{S}}$ ind $^{-1}$ & $\mathrm{P}_{\mathrm{G}}$ ind $^{-1}$ & $\mathrm{P}_{\mathrm{S}} / \mathrm{P}_{\mathrm{G}}$ & Source \\
\hline Mellita quinquiesperforata & Florida & 0.779 & 0.402 & 0.34 & Lane 1977 \\
Moira atropes & Florida & 0.235 & 0.102 & 0.30 & Moore and Lopez 1966 \\
Parechinus angulosus & S. Africa & 0.385 & 0.089 & 0.18 & Greenwood 1980 \\
Strongylocentrotus droebachiensis & Canada & 0.076 & 0.018 & 0.19 & Miller and Mann 1973 \\
Sterechinus antarcticus & Weddell Sea & 0.010 & 0.021 & 0.48 & Brey 1991 \\
Sterechinus neumayeri & McMurdo Station & 0.082 & 2.108 & 0.96 & present study \\
Sterechinus neumayeri & C. Evans & 0.039 & $\mathbf{1 . 6 7 6}$ & 0.98 & present study \\
\hline
\end{tabular}

${ }^{a}$ Gonad mass $\mathrm{M}_{\mathrm{G}}$ was determined in specimens collected in February by Brey and Gutt (1991), i.e. most likely after spawning. Pre-spawning gonad mass was estimated by $2 \times \mathrm{M}_{\mathrm{G}}$ in February 
E. C. Armitage, 7 yr at C. Evans and 6 yr at New Harbor (Fig. 6). It is unlikely that divers collecting echinoids overlooked juveniles completely, hence we have to conclude that no successful recruitment had occurred since $1985 / 86$. This is in sharp contrast to a $S$. neumayeri population sampled on the Weddell Sea shelf, where half of the population consisted of individuals $<15 \mathrm{~mm}$ (Brey and Gutt 1991). Recruitment of echinoderms has been found to be quite sporadic in many cases (e.g. Ebert 1983), but additional studies suggest a common pattern of recruitment in McMurdo Sound benthos. McClintock et al. (1988) found no juveniles of the sea star Odontaster validus during $1.5 \mathrm{yr}$ of regular sampling. Dayton (1979) found little or no recruitment in several sponge species over a $10 \mathrm{yr}$ period. Dayton (1989) reported almost no recruitment of marine invertebrates to settling plates during $5 \mathrm{yr}$ of exposure, but found a multi-species colonization of the same plates some years later. Similarly, Pearse and Pearse (1991) found very little recruitment on glass slides after 1 yr of exposure. Recruitment success of many species in McMurdo Sound is likely to be controlled by a common physical factor, as suggested by Dayton (1989). This factor may be the current regime, duration and extension of sea-ice cover or anchor ice formation, or time and amount of melt water discharge. Interannual variations in such factors may provide favourable conditions for recruitment only once every several years.

Comparison with Sterechinus neumayeri on the Weddell Sea shelf

Sterechinus neumayeri is the dominant echinoid species on the upper shelf and slope $(100$ to $450 \mathrm{~m})$ of the Antarctic continent, whereas below $450 \mathrm{~m}$ the conspecific $S$. antarcticus is more abundant (Brey and Gutt 1991). Brey (1991) investigated the population dynamics of $S$. antarcticus in the Weddell Sea, but growth and production of $S$. neumayeri were not analyzed.

Abundance and biomass of Sterechinus neumayeri in the Weddell Sea, 0.121 ind $^{-2}$ and $0.007 \mathrm{~g} \mathrm{AFDM}$ $\mathrm{m}^{-2}$, are significantly lower than in McMurdo Sound. The mean jaw size/test diameter ratio of $S$. neumayeri on the Weddell Sea shelf, 0.267 (SD $\pm 0.019 ; N=163)$ is much higher than at any of the four sites in McMurdo Sound (0.201 to 0.247), indicating that living conditions for echinoids are even better at E. C. Armitage than on the shelf below $100 \mathrm{~m}$. Since average temperature on the Weddell Sea shelf (about $-1^{\circ} \mathrm{C}$ ) is higher than the average temperature in McMurdo Sound (about $-1.8^{\circ} \mathrm{C}$ ), we assume food supply to be the major difference between the two systems. On the Weddell Sea shelf, sedimentation from the euphotic zone is the primary source of food. This shows great interannual and spatial variability, but on the average does not exceed a few grams of carbon per year (Bodungen et al. 1988; Bathmann et al. 1991; Schalk et al. 1993). In eastern McMurdo Sound (C. Evans and McMurdo Station), potential food levels are comprised of at least $12 \mathrm{~g} \mathrm{C} \mathrm{m}^{-2} \mathrm{yr}^{-1}$ benthic microalgae production, plus $21 \mathrm{~g} \mathrm{C} \mathrm{m}^{-2} \mathrm{yr}^{-1}$ sedimentation, plus seal faeces and macroalgal production (Table 1). Food levels on the western side of the Sound (New Harbor) are lower (Table 1), but still above the sedimentation rates recorded on the Weddell Sea shelf.

Significance of Sterechinus neumayeri in the McMurdo system

Limited data on growth efficiency $(100 \times$ production/consumption) for echinoids range between 5 and 30\% (Miller and Mann 1973; Lane 1977; Propp 1977; Greenwood 1980). Based on an average growth efficiency of $11 \%$, we estimated consumption by Sterechinus neumayeri in McMurdo Sound to be $10.9 \mathrm{~g} \mathrm{C} \mathrm{m}^{-2} \mathrm{yr}^{-1}$ at C. Evans, $4.0 \mathrm{~g} \mathrm{C} \mathrm{m}^{-2} \mathrm{yr}^{-1}$ at McMurdo Station and $3.0 \mathrm{~g} \mathrm{C} \mathrm{m}^{-2} \mathrm{yr}^{-1}$ at New Harbor (assuming $1 \mathrm{~g} \mathrm{AFDM}=0.5 \mathrm{~g} \mathrm{C}$ ). These figures correspond to $21 \%$ (C. Evans), 12\% (McMurdo Station), and 30\% (New Harbor) of the estimated sedimentation and benthic microalgal production (Dayton et al. 1986; Knox 1990; Barry et al. 1994; see also Table 1). Even if other potential food sources such as seal faeces and macroalgal debris are taken into account, $S$. neumayeri seems to consume a significant share of total food available to the benthos of McMurdo Sound.

If the populations of Sterechinus neumayeri in McMurdo Sound are assumed to be in a steady state, the amount of food consumed by predators of this sea urchin approximates somatic production, $0.03 \mathrm{~g} \mathrm{C}$ $\mathrm{m}^{-2} \mathrm{yr}^{-1}$ at C. Evans, $0.02 \mathrm{~g} \mathrm{C} \mathrm{m}^{-2} \mathrm{yr}^{-1}$ at McMurdo Station and $<0.01 \mathrm{~g} \mathrm{C} \mathrm{m}^{-2} \mathrm{yr}^{-1}$ at New Harbor (Table 6). However, gonad production is much higher than somatic production, $1.17 \mathrm{~g} \mathrm{C} \mathrm{m}^{-2} \mathrm{yr}^{-1}$ at $\mathrm{C}$. Evans, $0.42 \mathrm{~g} \mathrm{C} \mathrm{m}^{-2} \mathrm{yr}^{-1}$ at McMurdo Station and $0.32 \mathrm{~g} \mathrm{C} \mathrm{m}^{-2} \mathrm{yr}^{-1}$ at New Harbor (Table 6). The obvious discrepancy between gonad output and recruitment success indicates most gonad production is lost. Since eggs and sperms are released into the water column and since pelagic larval development takes nearly 4 mo to complete (Bosch et al. 1987), a significant portion of gonad production may be consumed by pelagic organisms, indicating a strong "upward" coupling between benthic and pelagic components of the community food web.

\footnotetext{
Acknowledgements We wish to acknowledge the Antarctic Support Associates, the Antarctic Support Services of the National Science Foundation (NSF), and the US Naval Antarctic Support Force for providing logistical support. T. Brey was supported by a grant from
} 
NSF during a three month stay at UCSC. NSF also supported $\mathbf{J}$. Pearse and L. Basch (Grant DPP-88354) and J. McClintock and M. Slattery (Grant DPP-9118864) when the samples were collected. We thank J. Heine, J. Mastro, B. Baker and M. Hamann for assisting with collections of sea urchins at C. Evans. This is Alfred Wegener Institute Publication No. 914.

\section{References}

Barry JP (1988) Hydrographic patterns in McMurdo Sound, Antarctica and their relationship to local benthic communities. Polar Biol 8: 377-391

Barry JP, Dayton PK (1988) Current patterns in McMurdo Sound, Antarctica and their relationship to local biotic communities. Polar Biol 8: 367-376

Barry JP, Dayton PK, Hansen JA (1994) Pelagic-benthic coupling in McMurdo Sound, Antarctic. In: Collection of Abstracts of the 6th Biological Symposium of SCAR, Venice 1994, SCAR, Venice, $\mathrm{p} 15$

Bathmann U, Fischer G, Müller PJ, Gerdes D (1991) Short-term variations in particulate matter sedimentation off Kapp Noevegia, Weddell Sea, Antarctica: relation to water mass advection, ice cover, plankton biomass and feeding activity. Polar Biol 11: $185-195$

Birkeland C, Chia FS (1971) Recruitment risk, growth, age and predation in two populations of sand dollars, Dendraster excentricus (Eschscholtz). J exp mar Biol Ecol 6: 265-278

Bodungen B v, Nöthig EM, Sui Q (1988) New production of phytoplankton and sedimentation during summer 1985 in the southeastern Weddell Sea. Comp Biochem Physiol 90B: 475-487

Bosch I, Beauchamp A, Steele ME, Pearse JS (1987) Development, metamorphosis, and seasonal abundance of embryos and larvae of the antarctic sea urchin Sterechinus neumayeri. Biol Bull mar biol Lab, Woods Hole 173: 126-135

Brey T (1991) Population dynamics of Sterechinus antarcticus (Echinodermata: Echinoidea) on the Weddell Sea Shelf and slope, Antarctica. Antarctic Sci 3: 251-256

Brey T, Gutt $J$ (1991) The genus Sterechinus (Echinodermata: Echinoidea) on the Weddell Sea shelf and slope (Antarctica): distribution, abundance and biomass. Polar Biol 11: 227-232

Crapp GB, Wills ME (1975) Age determination in the sea urchin Paracentrotus lividus (Lamarck) with notes on the reproductive cycle. J exp mar Biol Ecol 20: 157-178

Crisp DJ (1984) Energy flow measurements. In: Holme NA, McIntyre AD (eds) Methods for the study of marine benthos. Blackwell Scientific, Oxford, pp 284-372

Dayton PK (1979) Observations of growth, dispersal and population dynamics of some sponges in McMurdo Sound, Antarctica. In: Levi C, Boury-Esnault $\mathrm{N}$ (eds) Sponge biology. Centre National, Paris, pp 271-289

Dayton PK (1989) Interdecadal variation in an Antarctic sponge and its predators from oceanographic climate shifts. Science, NY 245: $1484-1486$

Dayton PK, Oliver JS (1977) Antarctic soft-bottom benthos in oligotrophic and eutrophic environments. Science, NY 197: 55-58

Dayton PK, Robillard GA, Paine RT (1970) Benthic faunal zonation as a result of anchor ice at McMurdo Sound, Antarctica. In: Holdgate MW (ed) Antarctic ecology. Vol. 1. Academic Press, New York

Dayton PK, Robillard GA, Paine RT, Dayton LB (1974) Biological accommodation in the benthic community at McMurdo Sound, Antarctica. Ecol Monogr 44: 105-128

Dayton PK, Watson D, Palmisano A, Barry JP, Oliver JS, Rivera D (1986) Distribution patterns of benthic microalgal standing stock at McMurdo Sound, Antarctica. Polar Biol 6: 207-213

Dearborn JH (1965) Ecological and faunistic investigations of the marine benthos at McMurdo Sound, Antarctica. PhD thesis, Stanford University, California
Ebert TA (1968) Growth rates of the sea urchin Strongylocentrotus purpuratus related to food availability and spine abrasion. Ecology 49: 1075-1091

Ebert TA (1980) Relative growth of sea urchin jaws: an example of plastic resource allocation. Bull mar Sci 30: 467-474

Ebert TA (1983) Recruitment in echinoderms. In: Jangoux M, Lawrence JM (eds) Echinoderm studies. Balkema, Rotterdam

Ebert TA (1988) Calibration of natural growth lines in ossicles of two sea urchins, Strongylocentrotus purpuratus and Echinometra mathaei, using tetreacycline. In: Burke RD, Mladenov PV, Lambert P, Parsley RL (eds) Echinoderm biology. Balkema, Rotterdam, pp 434-444

Gage J (1992) Natural growth bands and growth variability in the sea urchin Echinus esculentus: results from tetracycline tagging. Mar Biol 114: 607-616

Gage JD, Tyler PA (1985) Growth and recruitment of the deep-sea urchin Echinus affinis. Mar Biol 90: 41-53

Greenwood PJ (1980) Growth, respiration and tentative energy budgets for two populations of the sea urchin Parechinus angulosus (Leske). Estuar cstl mar Sci 10: 347-367

Knox GA (1990) Primary production and consumption in McMurdo Sound, Antarctica. In: Kerry KR, Hempel G (eds) Antarctic ecosystems. Springer, Berlin, New York, pp 115-128

Kobayashi S, Tahi J (1969) Calcification in sea urchins. I. A tetracycline investigation of growth of the mature test in Strongylocentrotus intermedius. Calcif Tiss Res 4: 210-223

Lane JM (1977) Bioenergetics of the sand dollar, Mellita quinquiesperforata (Leske, 1778). PhD thesis, University of South Florida, Miami

Levitan DR (1991) Skeletal changes in the test and jaws of the sea urchin Diadema antillarum in response to food limitation. Mar Biol 111: 431-435

McClintock J (1994) Trophic biology of antarctic shallow-water echinoderms. Mar Ecol Prog Ser 111: 191-202

McClintock JB, Pearse JS, Bosch I (1988) Population structure and energetics of the shallow-water antarctic sea star Odontaster validus in contrasting habitats. Mar Biol 99: 235-246

Miller KA, Pearse JS (1991) Ecological studies of seaweeds in McMurdo Sound, Antarctica. Am Zool 31: 35-48

Miller RJ, Mann KH (1973) Ecological energetics of the seaweed zone in a marine bay on the Atlantic coast of Canada. IIII. Energy transformations by sea urchins. Mar Biol 18: 99-114

Moore HB, Lopez NN (1966) The ecology and productivity of Moira atropes (L.). Bull mar Sci 16: 648-667

Palmisano AC, SooHoo JB, Sullivan CW (1985) Photosynthesisirradiance relationșhips in sea ice microalgae from McMurdo Sound, Antarctica. J Phycol 21: 341-346

Pawson DL (1969) Echinoidea. Antarctic Map Folio Ser (Folio Am geogr Soc) 11: 3841

Pearse JS (1965) Reproductive periodicities in several contrasting populations of Odontaster validus Koehler, a common Antarctic asteroid. Antarctic Res Ser 5: 39-85

Pearse JS, Bosch I (1991) Fig. 10. In: Pearse JS, Cameron RA Echinodermata: Echinoidea. In: Giese AC, Pearse JS, Pearse VB (eds) Reproduction of marine invertebrates. Vol. IV. Echinoderms and lophophorates. Boxwood Press, Pacific Grove, California

Pearse JS, Giese AC (1966) Food, reproduction and organic constitution of the common antarctic echinoid Sterechinus neumayeri (Meissner). Biol Bull mar biol Lab, Woods Hole 130: $387-401$

Pearse JS, Pearse VB (1975) Growth zones in the echinoid skeleton. Am Zool 15: 731-753

Pearse JS, Pearse VB, Davis KK (1986) Photoperiodic regulation of gametogenesis and growth in the sea urchin Strongylocentrotus purpuratus. J exp Zool 237: 107-118

Pearse VB, Pearse JS (1991) Year-long settling plate study yields no Antarctic placozoans, and surprisingly little else. Antarctic J US 26: $149-150$ 
Peterson CH (1982) The importance of predation and intra- and interspecific competition in the population biology of two infaunal suspension-feeding bivalves, Protothaca staminea and Chione undatella. Ecol Monogr 52: 437-475

Peterson CH, Beal BF (1989) Bivalve growth and higher order interactions: importance of density, site and time. Ecology 70: $1390-1404$

Press WH, Flannery BP, Teukolsky SA, Vetterling WT (1986) Numerical recipes. The art of scientific computing. Cambridge University Press, Cambridge

Propp MV (1977) Ecology of the sea urchin Strongylocentrotus droebachiensis of the Barents Sea: metabolism and regulation of abundance. Soviet J mar Biol 3: 27-37

Ricker WE (1973) Linear regression in fishery research. J Fish Res Bd Can 30: 409-434
Rivkin RB (1991) Seasonal patterns of planktonic production in McMurdo Sound, Antarctica. Am Zool 31: 5-16

Schalk PH, Brey T, Bathmann U, Arntz W, Gerdes D, Diekmann G, Ekau W, Gradinger R, Plötz J, Nöthig EM, Schnack-Schiel SB, Siegel V, Smetacek V, Van Franeker JA (1993) Towards a conceptual model for the Weddell Sea ecosystem. In: Christensen V, Pauly D (eds) Trophic models of aquatic ecosystems. ICLARM Conference Proceedings 26. ICLARM, Manila, pp 323-337

Schnute J (1981) A versatile growth model with statistically stable parameters. Can J Fish aquat Sciences 38: 1128-1140

Yakovlev SN (1983) Reproductive cycle of antarctic sea urchin Sterechinus neumayeri in Davis Sea. Soviet $\mathbf{J}$ mar Biol 9: 265-270 